Wioletta Jóźwiak-Majchrzak

Dom Samotnej Matki im. Stanisławy Leszczyńskiej w Łodzi

\title{
Wsparcie matek w trudnej sytuacji życiowej w Domu Samotnej Matki w Łodzi
}

\author{
Support of mothers in a difficult living situation \\ in the House of Single Mother in Łódź
}

\begin{abstract}
Abstrakt
Artykuł ten jest zapisem obserwacji i refleksji nad praktyką pracy socjalnej prowadzonej w Domu Samotnej Matki w Łodzi w oparciu o wewnętrzne dokumenty programowe np. „Program wychodzenia z kryzysu dla kobiet w ciąży i rodzin zagrożonych wykluczeniem społecznym w Domu Samotnej Matki im. Stanisławy Leszczyńskiej w Łodzi”, „Księga procedur i standardów obowiązujących w Domu Samotnej Matki w Łodzi". Poddano analizie dokumentację matek - zapisy sesji socjalnych, ewidencję pracy, diagnozy adaptacyjne oraz Indywidualne Programy Usamodzielnienia. Celem jest ukazanie problemu uzależnienia od alkoholu w grupie matek, które mieszkają w Domu Samotnej Matki w Łodzi.
\end{abstract}

Słowa kluczowe: dom samotnej matki, macierzyństwo, wsparcie

Dom Samotnej Matki w Łodzi im. Stanisławy Leszczyńskiej w Łodzi od 27 lat udziela wsparcia samotnym kobietom w ciąży i z dziećmi. Placówka dysponuje 60 miejscami dla kobiet i dzieci i jest najnowocześniejszą oraz największą placówką tego typu w Polsce. W Domu Samotnej Matki udziela się wsparcia w zakresach: interwencyjnym, potrzeb bytowych oraz opiekuńczo-wspomagającym. Podstawowym dokumentem określającym zasady i zakres pracy jest Rozporządzenie Ministra Polityki Społecznej z dnia 8 marca 2005 r. w sprawie domów dla matek z małoletnimi dziećmi i kobiet w ciąży. Matki otoczone są pomocą personelu (pedagog, terapeuta, położna, pracownik socjalny, interwent kryzysowy, wychowawca). Mają zagwarantowane podstawowe warunki bytowe oraz anonimowość i dyskrecję. Poprzez pomoc prawną i medyczną, pracę opiekuńczą, wychowawczą i psychoterapeutyczną samotne matki mogą przygotować się do podjęcia trudu wychowania dziecka i samodzielnego życia. Na ile jest to możliwe, podejmowane są próby nawiązania kontaktu z rodziną i środowiskiem. W placówce dla matek oczekujących urodzenia się dziecka prowadzona jest Szkoła Rodzenia. Prowadzone są warsztaty z terapeutą, położną oraz z pracownikiem socjalnym z zakresu usamodzielnienia. Każda z mam ma swój pokój z dostępem do łazienki, kuchni i pralni oraz otrzymuje trzy posiłki dziennie. Efektywne wsparcie matek w trudnej sytuacji życiowej polega na prowadzeniu programów usamodzielnienia. $Z$ każdą z matek zawierany jest kontrakt usamodzielnienia, w którym określa ona zadania do realizacji 
w celu zmiany swojej sytuacji. Kobiety są kierowane również do prawnika lub do grupy wsparcia dla ofiar przemocy lub osób współuzależnionych poza Ośrodkiem - na miejscu brakuje personelu w tym zakresie. W Domu Samotnej Matki brakuje środków na zatrudnienie prawnika, terapeuty uzależnień, psychologa. Kolejnym obszarem jest pomoc materialna i emocjonalna w usamodzielnieniu. Obejmuje ona warsztaty dotyczące usamodzielnienia, Grupy Wsparcia dla młodych matek (16-24 lata) oraz trening umiejętności ekonomicznych i zaradnościowych (np. gotowanie). Jest też możliwość bezpłatnego kompletowania mebli czy sprzętu do nowego lokalu. Personel pomaga również przy organizacji przeprowadzki i w urządzeniu się. Każda z form tej pomocy jest świadczona dla mieszkanek nieodpłatnie, a zadanie to jest finansowane ze środków gminy i dzięki wsparciu darczyńców.

Do głównych powodów skierowania do Domu Samotnej Matki należą: bezdomność, przemoc w rodzinie, wykluczenie finansowe, konflikty w rodzinie, uzależnienia, niepełnosprawność, zerwane relacje z rodziną biologiczną matki, problemy opiekuńczo-wychowawcze i inne sytuacje kryzysowe matek ciężarnych i matek z małymi dziećmi. W trakcie roku DSM podejmuje pracę z około 70 rodzinami rocznie - długość pobytów bywa różna: od kilku dni do 2 lat.

Kobiety zgłaszają się najczęściej do DSM z własnej inicjatywy (43\%), są kierowane przez Ośrodki Pomocy Społecznej lub przez sąd. Wśród podopiecznych DSM $66 \%$ to kobiety z wykształceniem podstawowym. Wiek mieszkanek przedstawia się następująco: 15-17 lat - 3\%, 18-25 lat - 58\%, 26-35 lat - 31\%, 36-45 lat - 8\%. Blisko $90 \%$ to kobiety bezrobotne, w tym $70 \%$ z nich posiada status osoby bezrobotnej bez prawa do zasiłku, $20 \%$ utraciły ten status z powodu nie stawienia się w urzędzie pracy. Pozostałe $10 \%$ pracuje lub uczy się. Nie ma szczegółowych informacji o sytuacji kobiet po opuszczeniu DSM. Według dokumentów wypełnianych przy opuszczeniu: $31 \%$ nie podaje miejsca przebywania, $18 \%$ powraca do rodzin, $5 \%$ wyprowadza się do otrzymanych lokali socjalnych, $11 \%$ decyduje się na wynajem. Dla 20\% kobiet pobyt w Domu Samotnej Matki jest powtórny z zaznaczeniem, że przy pierwszym pobycie nie ukończyły one programu usamodzielnienia.

Analiza danych z corocznych sprawozdań z realizacji zadań DSM oraz doświadczenie w udzielanej pomocy dają obraz grupy adresatów i wskazują na obszary ryzyka i deficyty podopiecznych: niskie wykształcenie; brak zasobów lokalowych; powroty do naturalnych środowisk, z którymi nie jest podejmowana praca; bezrobocie; znaczące braki w znajomości praw obywatelskich, pacjenta, pracownika, konsumenta; utrudniony dostęp do informacji publicznej i obowiązków państwa wobec obywateli oraz wykluczenie finansowe.

Zasobami najczęściej są siły matek, które są wyłaniane po uzyskaniu bezpiecznych warunków lokalowych (ustaje lęk przed zagrożeniem utraty miejsca pobytu) oraz życiowych (zapewnienie podstawowych potrzeb - miejsce do spania, łazienka, ciepłe i urozmaicone posiłki, środki higieniczne dla siebie i dziecka, leki). Te warunki w połączeniu ze wsparciem emocjonalnym i informacyjnym dają poprawę i stabilizację sytuacji klientki. W tych okolicznościach ujawniają się umiejętności zaradnościowe klientek, talent, a przede wszystkim nadzieja matki na zmianę swojej sytuacji i poprawne relacji macierzyńskiej oraz wzrost poczucia własnej wartości poprzez nabycie/odzyskanie decyzyjności. 
Wsparcie społeczne to przede wszystkim pomoc dostępna dla jednostek lub grupy w sytuacjach trudnych, stresowych czy przełomowych. Wsparcie społeczne człowiek otrzymuje ustawicznie w życiu codziennym, w czasie ciągłych interakcji z innymi ludźmi, zaś zapotrzebowanie na nie wzrasta w sytuacjach trudnych. W interakcji konieczna jest spójność między potrzebami biorcy a rodzajem udzielanego wsparcia. Celem tej interakcji jest zbliżenie do rozwiązywania problemu. Celem interakcji wspierającej jest również ogólne podtrzymanie, zmniejszenie stresu, opanowanie kryzysu przez towarzyszenie, tworzenie poczucia przynależności, bezpieczeństwa i nadziei. Oferowana pomoc powinna być dostosowana do potrzeb, trafna jakościowo i ilościowo. Nietrafna pomoc otoczenia może przerodzić się w obciążenie. Ważna jest zasada pomocy polegająca na dostarczaniu takiego wsparcia, aby człowiek umiał sobie sam pomóc. Kluczowe dla udzielanego wsparcia jest rozumienie jego potrzeby i rozumienie sytuacji kryzysowej przez podopiecznego oraz aktywne podejmowanie działań i zasada prawdomówności, regularnego kontaktu i systematyczności.

Przy realizacji Planów Usamodzielnienia potrzebne jest powtórzenie warunków osiągnięcia celu, a mianowicie: niezbędnym warunkiem realizacji tych zadań jest otwarcie się na działania pomocowe (czyli gotowość przyjęcia pomocy), wytrwałość w dążeniu do celu, a co najważniejsze - motywacja do działania, której fundamentem powinna być wizja samodzielnego i szczęśliwego życia rodzinnego i społecznego.

W pracy w DSM przyjmuje jako wskazówkę do działania zdanie Bila Draytona: „Nie trzeba ludziom dawać ryby ani nawet wędki - trzeba zrewolucjonizować system rybołówstwa". Personel w pracy z matką modeluje sytuacje odzyskania przez nią kontroli nad własnym życiem - poprzez odzyskanie sprawstwa, brania odpowiedzialności za własne decyzje oraz nabycie niezależności emocjonalnej - obserwuje się, że nauka tych kompetencji jest nowa dla matek.

W dokumencie programowym Program wychodzenia z kryzysu dla kobiet w ciąży i rodzin zagrożonych wykluczeniem społecznym w Domu Samotnej Matki im. Stanisławy Leszczyńskiej w Łodzi jako jeden z obszarów działania omówiono Motywowanie i pomoc w podjęciu leczenia (terapii) w przypadku uzależnień i/lub problemów psychicznych. Podopieczni, których funkcjonowanie może wskazywać na uzależnienie, motywowani są do kontaktu z instytucjami zajmującymi się leczeniem uzależnień w celu konsultacji. Udzielane są porady i informacje dotyczące ofert pomocowych placówek terapeutycznych. W DSM w Łodzi każda matka podpisuje zgodę na badania alkomatem i wykonanie testów z moczu na obecność narkotyków. W regulaminie placówki jest zapis o zakazie spożywania i posiadania środków psychoaktywnych. Wyzwaniem w pracy jest sytuacja, kiedy kobieta ciężarna spożywa środki (narkotyki, alkohol, dopalacze) i nie identyfikuje się z problemem. Przyjęta jest Procedura postępowania w przypadku naruszenia regulaminu w związku z zażyciem lub posiadaniem używek. W sytuacjach, kiedy mieszkanka łamie regulamin w punkcie dotyczącym zakazu spożywania alkoholu, jest z nią prowadzona praca w kierunku obowiązkowej konsultacji u terapeuty uzależnień i podjęcia terapii. Taka terapia jest prowadzona poza Ośrodkiem i matka na nią dochodzi. DSM stara się zapewnić opiekę wolontariusza nad dzieckiem matki uzależnionej na czas trwania terapii. Matka jest informowana 
o warunkowym pobycie i ewentualnie proponuje się przejście do ośrodka specjalistycznego, w którym można przebywać z dzieckiem. Od 2018 r. w związku ze zwiększeniem się liczby takich sytuacji w DSM zatrudniono lekarza psychiatrę.

Problem uzależnienia od alkoholu pojawia się wśród matek w DSM dwojako:

1. Matki współuzależnione - izolujące się od środowiska uzależnionego od alkoholu (rodzice, partnerzy, rodzeństwo, dziadkowie):

- współuzależnienie jawne - matki, które uciekają z powodu uzależnienia członków rodziny z wyboru własnego (współuzależnienie jawne uświadomione) lub na wniosek służb pomocowych (współuzależnienie nieuświadomione);

- współuzależnienie ukryte - matki izolujące się przed przemocą, ale zaprzeczające problemowi uzależnienia. Problem uzależnienia od alkoholu sprawcy jest niezdiagnozowany i nieuświadomiony „On bił tylko mnie - dzieciom nigdy nic nie zrobił”, ,jak miał pracę, to nie pił”, „on nie potrzebuje terapii, bo tak dużo nie pije”, "czasami sobie wypił".

\section{Matki uzależnione:}

- uzależnienie jawne (jawi się tu jako zagrożenie utraty dzieci - poprzez ich umieszczenie w formie pieczy zastępczej). Często uzależnienie nie jest uświadomione i matka nie utożsamia się z problemem. To matki, którym służby pomocowe (kuratorzy rodzinni, asystenci rodziny, dzielnicowi, pracownicy socjalni) stawiają warunek - „Nie może Pani tu zostać - musi iść Pani do Ośrodka”. To kobiety, które mają „ostatnią szansę, żeby się ogarnąć” - jak same mówią. W tej grupie matek są kobiety, które przeszły terapię dla uzależnionych.

- uzależnienie ukryte - matki przyjmowane z innego powodu niż uzależnienie, najczęściej bezdomność lub niska zaradność w sprawach opiekuńczo-wychowawczych, ale w trakcie pracy i diagnozy klientki zostaje wyłoniony problem uzależnienia od alkoholu.

Omawiając temat uzależnień wśród matek, warto zaznaczyć problem świadomości dotyczącej FASD wśród kobiet ciężarnych i matek. Mimo prowadzonych działań edukacyjnych zauważa się, że wciąż powielane są stereotypy na temat picia w okresie ciąży. Wiedza o zjawisku jest mała, a lekarze prowadzący ciążę bardzo rzadko uświadamiają w tym zakresie. Ponadto klientki często zaniedbują opiekę zdrowotną w czasie ciąży.

Dla zobrazowania problemu przedstawia się historie:

Historia 1: Przyjęto matkę, która urodziła dziecko pod wpływem alkoholu. Matke przyjęto ze starszym dzieckiem, a noworodka umieszczono ze szpitala w Domu Dziecka. Na pytanie: Czy piła w ciąży? Odpowiadała, że nie. Zaznaczała, że jej matka jest alkoholiczką. Sama była związana z alkoholikiem i sprawcą przemocy. W wywiadzie okazało się, że spożywała alkohol w postaci piwa, ale zaprzeczała, że piła w ciąży, bo w jej rozumieniu „picie to upijanie się, tracenie kontroli nad sobą". Proszona o podanie różnic tych stanów mówiła: „Ja nie powiedziałam, że piłam, bo picie to jest tak jak moja matka, że pije trzy piwa i wódkę, a ja piłam tylko piwo i to na wieczór jak dziecko (starsze) już spało". W dokumentacjach medycznych brakuje pytania dotyczącego używania alkoholu. Klientka twierdzi, że $w$ szpitalu położniczym nie rozmawiano z nią o uzależnieniu, nie udzielono pomocy psychologicznej, po porodzie poinformowano ją o tym, że „dziecko nie 
wyjdzie z nią", nie przekazano postanowienia sądu. Klientka trafiła kilka dni po porodzie w poczuciu dużego wstydu, reprezentując myśli rezygnacyjne, wymagała szybkiej pomocy psychiatrycznej. W trakcie pobytu była hospitalizowana psychiatrycznie. Została osądzona jako „pijana matka”. Matka podczas sesji socjalnych wypowiada się: „Napiłam się, bo nie wiedziałam już, jak mam żyć, nie wiedziałam, co mam zrobić, byłam skończona". Zgłasza zaskoczenie na brak ocen w pracy z nią. Podjęła pracę, uregulowała swoją sytuację życiową, podjęła terapię indywidualną. Podczas kilku miesięcy pobytu nigdy nie złamała regulaminu.

Komentarz 1: Społeczeństwo ma tendencje do oceniania pijących ciężarnych, które pojawiają się w doniesieniach medialnych. Wyłania się obraz pijącej matki jako tej, która nie szuka pomocy, zaniedbuje siebie i ciążę, nie widzi dla siebie wyjścia, nie ma wsparcia w rodzinie, ma poczucie winy, czuje się bezradna, wstydzi się i nie wierzy w możliwość życiowej zmiany. Obserwuje się, że istnieją matki zmagające się z chorobą alkoholową, z samotnością, ubóstwem i odrzuceniem, którym należy pomóc.

Historia 2: Kobieta 25 lat, przyjęta w szóstym miesiącu ciąży. Została przyjęta interwencyjnie, o 6 rano zgłosiła się do placówki - była zaniedbana, głodna, przeziębiona i brudna. W czasie przyjęcia nie potrafiła odpowiadać na pytania, płaczliwa, zalękniona. Klientka nie stosuje się do regulaminu - nie wraca na ustalone godziny, a czasem na noce. Klientka była widziana przez świadków w sklepie z alkoholem. Klientka bez dochodu - kradnie rzeczy z placówki, aby zastawić je w lombardzie i mieć pieniądze na alkohol. Logiczny kontakt z klientką jest bardzo słaby. Jej umiejętności zaradnościowe są na niskim poziomie. Nie potrafi zadbać o siebie i ciążę. Klientka zaprzecza problemowi uzależnienia. Badania alkomatem wykazują obecność alkoholu. Praca nad motywacją jej do poddania się dobrowolnemu leczeniu nie ma szans na powodzenie, ponieważ nie zachodzą podstawowe warunki pracy nad motywacją (zasoby, relacje, korzystanie ze wsparcia). Jest to piąta ciąża klientki. Przebywała u nas kilka lat wcześniej. Toczą się sprawy dotyczące władzy rodzicielskiej. Nad żadnym z pięciorga dzieci nie sprawuje opieki. Klientka łamie regulamin notorycznie, nie wraca na noce, kradnie, przychodzi pod wpływem środków odurzających, obraża pracowników, wyzywa ich i grozi im. Otrzymane rzeczy, np. środki higieny, sprzedaje. Łamaniu regulaminu przyglądają się pozostałe mieszkanki. Pracownicy i dyrekcja odczuwają utratę autorytetu. W zespole pojawiają się różne sposoby rozwiązań. Klientka nie ma żadnych dokumentów (zniszczony dowód) oprócz książeczki ciąży.

Komentarz 2: Praca z ciężarną klientką uzależnioną i nie identyfikującą się z problemem uzależnieniem rodzi wiele etycznych dylematów. Wydalenie jej z ośrodka za łamanie regulaminu jest zagrożeniem dla jej nienarodzonego dziecka.

Praca z matką w kryzysie to szansa na danie jej możliwości rozwoju i uświadomienia wieloletnich zaniedbań środowiskowych rodzinnych i systemowych. Problem alkoholowy jest jednym z kontekstów jej historii. Na poznanie tej historii 
trzeba czasu, otwartości i szacunku. Funkcjonowanie ośrodka jako całodobowej placówki sprzyja nawiązaniu relacji. Społeczeństwo powinno uznać, że matki i ciężarne uzależnione są i powinno pamiętać, że matki, które wygrały swoje macierzyństwo i walkę z uzależnieniem, również istnieją.

Rekomenduje się wystrzeganie działań nieskutecznych, np. działanie od kryzysu do kryzysu, nieskoordynowanej pomocy - „każdy robi swoje”, kontroli zamiast współpracy, wyręczania zamiast wsparcia na rzecz pracy nad relacją, zasobami i udzielaniem wsparcia w kierunku usamodzielnienia. Praca z ciężarną i matką oraz udzielenie jej efektywnego wsparcia wymaga analizy jej sytuacji prawnej i społecznej, odkrywania zasobów, relacji, nauki kompetencji oraz pracy nad motywacją do osiągnięcia odbojności i samodzielności poprzez wzrost poczucia własnej wartości. System pomocowy powinien objąć szczególnymi działaniami edukacyjnymi, profilaktycznymi i pomocowymi kobiety ciężarne i matki uzależnione i zagrożone uzależnieniem.

\section{Abstract}

This article records the observations and reflection on the practice of social work carried out in the Single Mother's Home in Łódź, based on internal program documents.

Keywords: home of a single mother, motherhood, support 